\title{
Anti-mosquito plants as an alternative or incremental method for malaria vector control among rural communities of Bagamoyo District, Tanzania
}

Ester Innocent ${ }^{1 *}$, Ahmed Hassanali ${ }^{2}$, William NW Kisinza ${ }^{3}$, Prince PP Mutalemwa ${ }^{3}$, Stephen Magesa $a^{3,4}$ and Edmund Kayombo

\begin{abstract}
Background: Plants represent one of the most accessible resources available for mosquito control by communities in Tanzania. However, no documented statistics exist for their contribution in the management of mosquitoes and other insects except through verbal and some publications. This study aimed at assessing communities' knowledge, attitudes and practices of using plants as an alternative method for mosquito control among selected communities in a malaria-prone area in Tanzania.

Methods: Questionnaires were administered to 202 respondents from four villages of Bagamoyo District, Pwani Region, in Tanzania followed by participatory rural appraisal with village health workers. Secondary data collection for plants mentioned by the communities was undertaken using different search engines such as googlescholar, PUBMED and NAPRALERT.

Results: Results showed about $40.3 \%$ of respondents used plants to manage insects, including mosquitoes. A broad profile of plants are used, including "mwarobaini" (Azadirachta indica) (22.5\%), "mtopetope" (Annona spp) (20.8\%), "mchungwa/mlimau" (Citrus spp) (8.3\%), "mvumbashi/uvumbati" (Ocimum spp) (7.4\%), "mkorosho" (Anacadium occidentale) (7.1\%), "mwembe" (5.4\%) (Mangifera indica), "mpera" (4.1\%) (Psidium spp) and "maganda ya nazi" (4.1\%) (Cocos nucifera). Majority of respondents collected these plants from the wild (54.2\%), farms (28.9\%) and/or home gardens (6\%). The roles played by these plants in fighting mosquitoes is reflected by the majority that deploy them with or without bed-nets ( $p>0.55$ ) or insecticidal sprays ( $p>0.22$ ). Most respondents were aware that mosquitoes transmit malaria (90.6\%) while few respondents associated elephantiasis/hydrocele (46.5\%) and yellow fever (24.3\%) with mosquitoes. Most of the ethnobotanical uses mentioned by the communities were consistent with scientific information gathered from the literature, except for Psidium guajava, which is reported for the first time in insect control.

Conclusion: This survey has indicated some knowledge gap among community members in managing mosquito vectors using plant. The communities need a basic health education and sensitization for effective exploitation of this valuable tool for reducing mosquitoes and associated disease burdens. On the other hand, the government of Tanzania should strengthen advocacy of botanical pesticides development, registration and regulation for public health benefits because they are source of pest control tools people rely on them.
\end{abstract}

Keywords: Mosquitoes, Vector control, Ethno-knowledge, Medicinal plants, Azadirachta indica, Annona species

\footnotetext{
* Correspondence: einnocent@muhas.ac.tz

IInstitute of Traditional Medicine, Muhimbili University of Health and Allied

Sciences, P.O. Box 65001, Dar es Salaam, Tanzania

Full list of author information is available at the end of the article
} 


\section{Background}

Availability of healthcare services for improved diagnosis and treatment of mosquito-borne diseases have been considered as two crucial interventions in minimizing mortality and morbidity risk due to exposure to infected mosquitoes [1]. However, these alone cannot eliminate the high mosquito borne disease incidences in sub-Saharan Africa unless levels of infections and re-infections are substantially reduced through effective vector control mechanisms. Thus, a new strategy for control and prevention of mosquito-borne diseases, reinforcing linkages between health and environment and emphasizing Integrated Vector Management (IVM), has been advocated by WHO [1]. The strategy also stresses the importance of understanding the local vector ecology and local patterns of disease transmission. This is considered important in choosing the appropriate vector control tool from a range of the available options. IVM needs to be locally managed and flexible, with emphasis on decentralization, active community participation and harnessing of local knowledge [1]. In line with this understanding, Tanzania has since 2005 made a number of reforms in the health sector with most of the disease prevention and control program activities being planned and implemented at district level [2]. However, the current mosquito vector management efforts are focused on the use of Insecticide Treated Nets (ITN) and Indoor Residual Sprays (IRS). Very little effort has been directed towards the use of pesticidal plants that have been deployed by rural communities since time immemorial as a first line intervention in primary health care.

Furthermore, many of the synthetic insecticides available to-date faces challenges due to environmental contamination, resistance development by target insects and high deployment costs. This calls for the use of ecologically friendly and effective botanical insecticides as an alternative measure. The aim of present study, therefore, was to assess communities' knowledge, attitudes and practices of using plants as an alternative or incremental method for mosquito vector control among selected communities in a malaria-prone area of Bagamoyo district, Tanzania so as to know the existing and potential contribution of anti-insect plants in this endeavor. Specifically, insights generated from this study, are expected to add value to the current IVM strategies in rural communities where plants continue to be deployed in mosquito control.

\section{Methods}

\section{Study area and design}

Bagamoyo district is in Coast Region and it is allocated about $75 \mathrm{~km}$ north of Dar es Salaam which is the major city of Tanzania. The majority of the populations are ethnic groups of Wakwere, Wazaramo and Wazingua, however, other tribes co-exist in the area due to close proximity to Dar es Salaam. Majority of the population are Muslims; farmers and fishermen who practices Swahili Culture that was introduced by Arabs during the slavery and ivory trade in 19th century. The study was carried out in four villages of Yombo, Chansimba, Makurunge and Kongo (between $6^{\circ} 24^{\prime} 19^{\prime \prime}$ S: $38^{\circ} 50^{\prime} 31^{\prime \prime} \mathrm{E}$ and $6^{\circ}$ $29^{\prime} 03^{\prime \prime}$ S: $38^{\circ} 49^{\prime} 49^{\prime \prime}$ E; Figure 1). The four villages are vicinity to river Ruvu which flows to the Indian Ocean. Over-flooding during the rainy seasons between April-May and October-November creates temporary and permanent mosquito breeding water ponds in the vicinity, which contribute to high infectivity rates during these periods. In addition, selection of the villages was based on

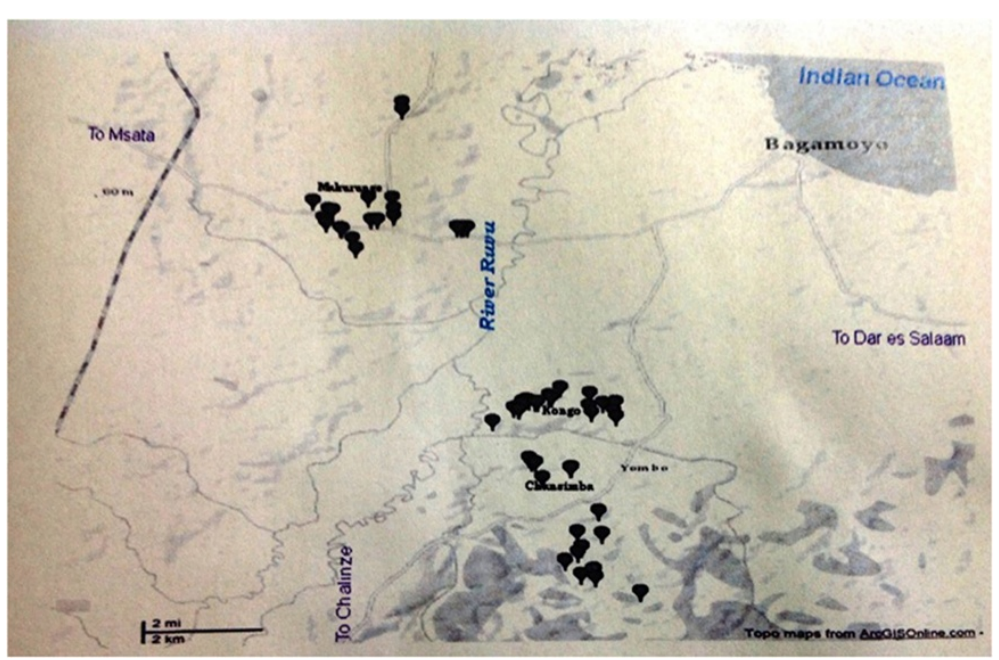

Figure 1 The map showing areas of concentrated water ponds in the four villages located along Ruvu River in Bagamoyo District. 
previously reported higher entomological inoculation rates [3] data, and malaria epidemiology, demography and entomological data of the study area [4-7]. The study was based on a cross-sectional design using self-administered questionnaires conducted in the selected local communities. Consented respondents (202) were randomly selected on the criteria that they were at least in the post-primary school age (i.e. 14 years and above).

Table 1 Respondents' socio-economic and demographic profile $(\mathrm{N}=202)$

\begin{tabular}{|c|c|c|c|c|c|c|}
\hline \multirow[t]{2}{*}{ Variable } & \multirow{2}{*}{$\begin{array}{c}\text { Total } \\
(\mathrm{N}=202)\end{array}$} & \multicolumn{4}{|c|}{ Number/proportion (\%) of respondents } & \multirow{2}{*}{$\begin{array}{c}x^{2} \\
\text { (p-value) }\end{array}$} \\
\hline & & Yombo & Chasimba & Kongo & Makurunge & \\
\hline \multicolumn{7}{|l|}{ Sex } \\
\hline Male & $106(52.5)$ & $28(58.3)$ & $25(45.5)$ & $23(46.9)$ & $30(60.0)$ & \multirow{2}{*}{$3.49(0.32)$} \\
\hline Female & $96(47.5)$ & $20(41.7)$ & $30(54.6)$ & $26(53.1)$ & $20(40.0)$ & \\
\hline \multicolumn{7}{|l|}{ Age group } \\
\hline$<15$ & $8(3.96)$ & $0(0.0)$ & $4(7.27)$ & $1(2.04)$ & $3(6.0)$ & \multirow{5}{*}{$21.41(0.05$} \\
\hline $15-25$ & $8(16.67)$ & $16(29.09)$ & $10(20.41)$ & $12(24)$ & $46(22.8)$ & \\
\hline $26-39$ & $110(54.5)$ & $22(45.8)$ & $31(56.4)$ & $29(59.2)$ & $28(56.0)$ & \\
\hline $40-55$ & $31(15.4)$ & $14(29.2)$ & $3(5.5)$ & $8(16.3)$ & $(12.0)$ & \\
\hline$>55$ & $7(3.5)$ & $4(8.3)$ & $1(1.8)$ & $1(2.0)$ & $1(2.0)$ & \\
\hline \multicolumn{7}{|l|}{ Marital status } \\
\hline Married & $118(60.2)$ & $31(67.4)$ & $23(42.6)$ & $31(67.4)$ & $33(66.0)$ & \multirow{5}{*}{$22.54(0.03)$} \\
\hline Single & $61(31.1)$ & $7(15.2)$ & $26(48.2)$ & $12(26.1)$ & $16(32.0)$ & \\
\hline Widow & $6(3.1)$ & $3(6.5)$ & $2(3.7)$ & $1(2.2)$ & $0(0.0)$ & \\
\hline Divorced & $5(2.6)$ & $2(4.4)$ & $1(1.9)$ & $2(4.4)$ & $0(0.0)$ & \\
\hline Cohabiting & $6(3.1)$ & $3(6.5)$ & $2(3.7)$ & $0(0.0)$ & $1(2.0)$ & \\
\hline \multicolumn{7}{|l|}{ Education level } \\
\hline No formal education & $22(11.0)$ & $7(14.6)$ & $3(5.6)$ & $7(14.3)$ & $5(10.0)$ & \multirow{5}{*}{$21.40(0.05)$} \\
\hline Primary school & $134(66.7)$ & $35(72.9)$ & $29(53.7)$ & $35(71.4)$ & $35(70.0)$ & \\
\hline Form IV & $38(18.9)$ & $5(10.4)$ & 18 (33.3) & $5(10.2)$ & $10(20.0)$ & \\
\hline High school & $4(2.0)$ & $0(0.0)$ & $2(3.7)$ & $2(4.1)$ & $0(0.0)$ & \\
\hline Higher education & $3(1.5)$ & $1(2.1)$ & $2(3.7)$ & $0(0.0)$ & $0(0.0)$ & \\
\hline \multicolumn{7}{|l|}{ Time of residential stay } \\
\hline$<=1$ year & $24(12.4)$ & $5(10.9)$ & $9(17.3)$ & $8(17.0)$ & $2(4.1)$ & \multirow{5}{*}{$15.40(0.22$} \\
\hline $2-5 y r s$ & $30(15.5)$ & $4(8.7)$ & $7(13.5)$ & $8(17.0)$ & $11(22.5)$ & \\
\hline $6-10$ yrs & $32(16.5)$ & $4(8.7)$ & $10(19.2)$ & $10(21.3)$ & $8(16.3)$ & \\
\hline $11-15$ years & $34(17.5)$ & $9(19.6)$ & $10(19.2)$ & $5(10.6)$ & $10(20.4)$ & \\
\hline$>15 \mathrm{yrs}$ & $74(38.1)$ & $24(52.2)$ & $16(30.8)$ & $16(34.0)$ & $18(36.7)$ & \\
\hline \multicolumn{7}{|l|}{ Types of homesteads } \\
\hline Mud and grass & $61(30.4)$ & $16(34.0)$ & $12(21.8)$ & 15 (30.6) & $18(36.0)$ & \multirow{5}{*}{$19.34(0.08$} \\
\hline Mud wall and metal roof & $101(50.3)$ & $26(55.3)$ & $25(45.5)$ & $28(57.1)$ & $22(44.0)$ & \\
\hline Block wall and grass roof & $1(0.5)$ & $0(0.0)$ & $0(0.0)$ & $0(0.0)$ & $1(2.0)$ & \\
\hline Block wall and metal roof & $37(18.4)$ & $4(8.5)$ & $18(32.7)$ & $6(12.2)$ & $9(18.0)$ & \\
\hline Block wall and tiles & $1(0.5)$ & $1(2.1)$ & $0(0.0)$ & $0(0.0)$ & $0(0.0)$ & \\
\hline \multicolumn{7}{|l|}{ Occupation } \\
\hline Peasant & $117(58.2)$ & $34(70.8)$ & $24(44.4)$ & $28(57.1)$ & $31(62.0)$ & \multirow{5}{*}{$28.3(0.005)$} \\
\hline Housewife & $24(11.9)$ & $4(8.3)$ & $5(9.3)$ & $10(20.4)$ & $5(10.0)$ & \\
\hline Self employed & $28(13.9)$ & $4(8.3)$ & $10(18.5)$ & $5(10.2)$ & $9(18.0)$ & \\
\hline Civil servant & $27(13.4)$ & $4(8.3)$ & $15(27.8)$ & $6(12.2)$ & $2(4.0)$ & \\
\hline Casual employment & $5(2.5)$ & $2(4.2)$ & $0(0.0)$ & $0(0.0)$ & $3(6.0)$ & \\
\hline
\end{tabular}


Table 2 List of the most invasive insects/organisms controlled by plants

\begin{tabular}{lllll}
\hline Sno. & Swahili name & Common english name & Order & No. of responses (\%) \\
\hline 1 & Mbu & Mosquito & Diptera & $30(30.3)$ \\
2 & Nyoka & Snake & Squamata & $15(15.3)$ \\
3 & Ng'e & Scorpion & Scorpiones & $11(11.1)$ \\
4 & Buibui & Spider & Argiope & $10(10.1)$ \\
5 & Siafu & Army ant & Hymenoptera & $6(6.1)$ \\
6 & Kunguni & Bed bug & Hemiptera & $6(6.1)$ \\
7 & Tandu & Centipede & Scolopendromorpha & $6(6.1)$ \\
8 & Mende & Cockroach & Blattaria & $4(4.0)$ \\
9 & Nyuki & Bee & Hymenoptera & $4(4.0)$ \\
10 & Mchwa & Termite & Blattaria & $3(3.0)$ \\
\hline
\end{tabular}

\section{Data collection}

Before commencement of the study, reconnaissance surveys were conducted in the study area. The purpose of the visits was to get acquainted with the study areas and discuss the project with district and village leaders. Leaders in all the four villages agreed to convene a meeting of the adult residents with the help of Village Health Workers (VHWs) who identified the participants based on our criteria. Informed collective agreement was made and other useful information was sought. Those who consented proceeded to filling in the self-administered questionnaires and then followed by in-depth interview in a focus group discussion. During filling of questionnaires those who did not know how to read and write were assisted to fill the questionnaires by the research team who asked them to respond to questions. Focus group discussion consisted of leaders of the village and village health workers whom together checked and confirm identity of the meaning and of any ambiguities. However, FGD did not affect the priority of list which was given by individuals when filling the questions. Semi-structured questionnaire and focus group discussions were translated in Swahili language (after being translated from the Standard English version). Published information on the plant species mentioned was gathered through literature search using google scholar, PubMED and NAPRALERT. The final results of the study were shared with all study participants during community feedback meetings at each of the study sites.

\section{Ethical considerations}

Scientific and ethical approval for the study (NIMR/HQ/ R.8a/Vol. IX/1093) was granted by the Medical Research Coordinating Committee (MRCC) of the National Institute for Medical Research and the institutional clearance was granted by the Senate, Research and Publication of the Muhimbili University of Health and Allied Sciences (MUHAS/RP/AEC/VOL.XIII/), Tanzania.

\section{Data analysis}

Quantitative data were double entered into a computer database using EpiData ${ }^{\circ}$ software. Responses from closedended questions in questionnaires were coded before

Table 3 Plants used for insect control in Bagamoyo District

\begin{tabular}{|c|c|c|c|c|}
\hline S. No & Swahili name & Species/Genus name (Voucher specimen number) & Family & No. of responses $(\%)^{*}$ \\
\hline 1 & Mwarobaini, mwarobaini kamili & Azadirachta indica (ITM 3080) & Meliaceae & $38(22.5)$ \\
\hline 2 & $\begin{array}{l}\text { Mtopetope, mtopetope mwitu, mtomoko, } \\
\text { mtomoko mwitu, mchekwa, mtopetope pori }\end{array}$ & $\begin{array}{l}\text { Annona squamosa (ASS-T-II), An. } \\
\text { senegalesis (OT 00353) }\end{array}$ & Annonaceae & $29(17.2)$ \\
\hline 3 & Mchungwa, limau & Citrus limonium (ITM 433) & Rutaceae & $14(8.3)$ \\
\hline 4 & Mvumbashi, uvumbati & Ocimum suave (ITM 445.0303) & Laminaceae & $13(7.7)$ \\
\hline 5 & Mkorosho & Anacardium occidentale (TMRU 2876) & Anacardiaceae & $12(7.1)$ \\
\hline 6 & Mwembe & Mangifera indica (TMRU 963) & Myrtaceae & $10(5.4)$ \\
\hline 7 & Mpera & Psidium guajava (TMRU 2880) & Myrtaceae & $7(4.1)$ \\
\hline 8 & Maganda ya nazi & Cocos nucifera (TMRU 1510) & Arecaceae & $7(4.1)$ \\
\hline 10 & Mstafeli, & An. muricata (OT 00351) & Annonaceae & $6(3.6)$ \\
\hline 11 & & Others & - & $34(22.1)$ \\
\hline
\end{tabular}

*Multiple responses were allowed. 
being entered into the computer. Data quality checking process was done and thereafter the database was exported to STATA 10 software for statistical analysis.

\section{Results}

\section{Socio-economic and demographic profile}

Respondents (202) were interviewed from four villages, Yombo (48), Chasimba (55), Kongo (49) and Makurunge (50). Majority of the respondents were of age ranging between 26-39 years (54.5\%) and were married (60.2\%). There was, however, no significant difference between the sex categories of the respondents $(p>0.32)$. Majority of the respondents had primary school level of education (66.7\%) and were peasants (58.2\%) who had stayed in the study villages for varying periods $(>15$ years, $38.1 \%$; $11-15$ years, $17.5 \%$; $6-10$ years, $16.5 \%$; $2-5$ years, $15.5 \%$; < 1 year, $12 \%)$. From the questionnaires and on general inspection of their homesteads, majority were of mud and metal roof $(50.3 \%)$ or mud and grass roof (30.4\%); the rest were of blocks with metal roof (18.4\%) and few with blocks and grass or blocks and tiles (Table 1).

\section{People's knowledge and practice on use of plants for controlling mosquitoes}

About 81 (40.3\%) of the respondents reported to have used plants to control arthropods including mosquitoes (30.3\%) and scorpions (11.1\%). Others were spiders, centipedes, army ants, bedbug, cockroaches, bees, termites, small ants, house flies, etc. Snakes which do not belong to the phylum arthropoda, was ranked second in terms of organisms that attack human habitats and it is also controlled with plant products. Most of the arthropods mentioned were vectors of important tropical diseases or cause other harm to humans (Table 2).

Further probing on the profiles of plants used in managing the arthropods identified Azadirachta indica, Annona spp, Ocimum spp., Citrus spp., Anacardium occidentale Mangifera indica, Psidium spp and Cocos nucifera as the plant species commonly used (Table 3). The distances travelled by members of the community to collect the plants were less than one kilometer for majority of respondents $(51.2 \%)$, while only $6.1 \%$ travelled up to $5 \mathrm{~km}$. Most of the plants are collected from the wild (54.2\%), with some from respondents' farms (28.9\%) and home gardens (6\%).

Respondents who acknowledged using plants in controlling mosquitoes had different modalities and time for usage. Most of them either use plants daily (56.3\%) or when need arises (25.0\%). Parts of the plants frequently mentioned for use include leaves (38.2\%) and roots (41.2\%). These are put on burning charcoal in containers placed at different locations inside the homesteads to generate smoke
Table 4 Knowledge and practice of using plants in mosquito controls among Bagamoyo communities

\begin{tabular}{|c|c|c|}
\hline Variable & $\begin{array}{c}\text { No. of } \\
\text { respondents }\end{array}$ & $\%$ \\
\hline \multicolumn{3}{|c|}{ How long does it take for the insect to die? } \\
\hline less than 1 hour & 11 & 34.38 \\
\hline $1-6$ hours & 14 & 43.75 \\
\hline $7-12$ hours & 6 & 18.75 \\
\hline 13-24 hours & 1 & 3.13 \\
\hline \multicolumn{3}{|l|}{ How frequent do you apply } \\
\hline once a day & 18 & 56.3 \\
\hline once a week & 2 & 6.3 \\
\hline once a month & 2 & 6.3 \\
\hline once a year & 2 & 6.3 \\
\hline once necessary & 8 & 25.0 \\
\hline \multicolumn{3}{|l|}{ Modality of using/applying the plant } \\
\hline Cut to pieces and distribution & 7 & 21.9 \\
\hline Ground fresh materials distribution & 4 & 12.5 \\
\hline Soaking and spraying & 5 & 15.6 \\
\hline Smoking & 14 & 43.8 \\
\hline Placed in a ceiling & 2 & 6.3 \\
\hline \multicolumn{3}{|c|}{ Distances traveled to harvest the plant } \\
\hline$<1 \mathrm{~km}$ & 42 & 51.2 \\
\hline $1-2 \mathrm{~km}$ & 17 & 20.7 \\
\hline $2-5 \mathrm{~km}$ & 6 & 7.3 \\
\hline \multicolumn{3}{|l|}{$5 \mathrm{~km}$} \\
\hline Where do you apply it & No & $\%$ \\
\hline Inside the house & 14 & 45.2 \\
\hline in dumping areas & 6 & 19.4 \\
\hline Around the house premise & 7 & 22.6 \\
\hline In water tanks & 3 & 9.7 \\
\hline In sewage systems & 1 & 3.2 \\
\hline Part of the plant used & No & $\%$ \\
\hline Stem & 1 & 2.9 \\
\hline Leaves & 13 & 38.2 \\
\hline Roots & 14 & 41.2 \\
\hline Fruits & 5 & 14.7 \\
\hline Seeds & 1 & 2.9 \\
\hline Place of harvesting the plant & No & $\%$ \\
\hline Farm & 24 & 28.9 \\
\hline Home garden & 5 & 6.0 \\
\hline Roadside & 2 & 2.4 \\
\hline Wild & 45 & 54.2 \\
\hline Forest reserve & 7 & 8.4 \\
\hline
\end{tabular}


Table 5 Knowledge of mosquito transmitted diseases, multiplication and control $(\mathrm{N}=202)$

\begin{tabular}{|c|c|c|}
\hline Variable & No* & $\%$ \\
\hline \multicolumn{3}{|l|}{ Knowledge of diseases caused by mosquitoes } \\
\hline Elephantiasis & 118 & 58.4 \\
\hline Hydrocele & 70 & 34.7 \\
\hline Malaria & 183 & 90.6 \\
\hline Yellow fever & 49 & 24.3 \\
\hline HIV & 14 & 6.9 \\
\hline All of the above & 1 & 0.5 \\
\hline \multicolumn{3}{|l|}{ Knowledge of places of mosquito breeding } \\
\hline Water and air & 22 & 10.9 \\
\hline Water and bush & 72 & 35.6 \\
\hline Stagnant water alone & 143 & 70.8 \\
\hline Air alone & 9 & 4.5 \\
\hline Bush alone & 43 & 21.3 \\
\hline Dumping sites & 71 & 35.1 \\
\hline Sewage systems & 92 & 45.5 \\
\hline Drainage systems & 53 & 26.2 \\
\hline Leaking taps & 27 & 13.4 \\
\hline \multicolumn{3}{|l|}{ Preventive measures } \\
\hline Using bednet & 128 & 63.4 \\
\hline Using treated bednet & 75 & 37.1 \\
\hline Using plants/herbs & 35 & 17.3 \\
\hline Filling stagnant water bodies & 121 & 59.9 \\
\hline Using insecticides residual sprays & 65 & 32.2 \\
\hline Keeping home premises clean & 69 & 34.2 \\
\hline Inspecting water bodies around the house premises & 46 & 22.8 \\
\hline Wearing long sleeves & 19 & 9.4 \\
\hline All of the above & 15 & 7.4 \\
\hline None of the above & 4 & 2.0 \\
\hline
\end{tabular}

${ }^{*}$ Multiple responses were allowed. and volatile emissions (45.2\%). According to the majority of the respondents $(78.2 \%)$, the process between application of the plant products and insects dying took less than six hours (Table 4). Other modalities of application of plant parts were placing ground fresh materials $(21.9 \%)$ or small pieces $(12.5 \%)$ at selected places within the homesteads, and soaking plant parts or powder in water and then spraying (15.6\%). Majority of the respondents appeared to target adult mosquitoes in their control efforts because most plant products were applied inside homesteads (45.2\%) rather than at dumping areas $(19.4 \%)$, water tanks $(9.7 \%)$ or outdoor sewage systems (3.2\%).

\section{Knowledge about mosquito transmitted diseases, multiplication and control}

Majority of respondents (97.8\%) were aware of disease agents transmitted by mosquitoes. Among the diseases mentioned included malaria (90.6\%), elephantiasis/ hydrocele (46.5\%) and yellow fever (24.3\%) (Table 5). Furthermore, a large proportion of respondents associated mosquito breeding and multiplication with stagnant water (70.8\%), dumping sites (35.1\%), sewages (45.5\%) and drainage systems (26.2\%). Others included uncleared bushes around the houses (35.6\%) and leaking taps (13.4\%). Further probing with respondents on mosquito preventive measures, identified bed-nets (63.4\%) and drying stagnant water bodies (59.9\%) as the best options, in addition to keeping home premises clean (34.2\%), using insecticides residual sprays (32.2\%) and using plants/herbs (17.3\%) (Table 5). However, majority of the respondents were not comfortable with reliance on only one preventive measure such as ITN, or use of plants/herbs or insecticide residual spray because responses showed no significant differences between the uses of the three methods in all the four villages surveyed (Table 6).

Table 6 Respondents' reliance on various mosquito preventive measures

\begin{tabular}{|c|c|c|c|c|c|c|}
\hline & \multicolumn{4}{|c|}{ Village } & \multirow[t]{2}{*}{ Total } & \multirow{2}{*}{$\begin{array}{c}x^{2} \\
\text { (p-value) }\end{array}$} \\
\hline & Yombo & Chasimba & Kongo & Makurunge & & \\
\hline \multicolumn{7}{|c|}{ Use of ITN } \\
\hline Yes & $14(30.4)$ & $23(42.6)$ & $19(41.3)$ & $21(42.9)$ & 77 (39.5) & $2.1(0.55)$ \\
\hline No & $32(69.6)$ & $31(57.4)$ & $27(58.7)$ & $28(57.1)$ & $118(60.5)$ & \\
\hline \multicolumn{7}{|c|}{ Use of plants/herbs } \\
\hline Yes & $3(6.4)$ & $10(18.5)$ & $9(18.8)$ & $13(26.5)$ & $35(17.7)$ & $6.82(0.08)$ \\
\hline No & $44(93.6)$ & $44(81.5)$ & $39(81.3)$ & $36(73.5)$ & $163(82.3)$ & \\
\hline \multicolumn{7}{|c|}{ Insecticide residual spray } \\
\hline Yes & $10(21.3)$ & $19(35.2)$ & $16(33.3)$ & $20(40.8)$ & $65(32.8)$ & $4.4(0.22)$ \\
\hline No & $37(78.7)$ & 35 (64.8) & $32(66.7)$ & $29(59.3)$ & $133(67.2)$ & \\
\hline
\end{tabular}




\section{Perceptions on the use of plants in mosquito control}

On respondents' attitude towards incorporating plants in mosquito management, their accessibility (26.7\%) and affordablility (29.2\%) were important factors (Table 7). The other reason highlighted was that the use of plants has been an old and familiar traditional practice (22.8\%). However, the respondents were willing and happy to participate in other community-based mosquito management practices, such as draining off or reducing formation of small stagnant water bodies around their houses (58.4\%), cleaning bushes (35.6\%) and applying safe insecticides on sizeable stagnant waters (34.2\%) (Table 7).

\section{Secondary data generated on ethnobotanical status and scientific investigations on the plants mentioned}

Secondary data collection on plants mentioned by the communities in Bagamoyo district was done by using different search engines such as Google Scholar, PubMED and NAPRALERT. Except for Psidium species

Table 7 Attitude about elimination of mosquitoes $(\mathrm{N}=\mathbf{2 0 2})$

\begin{tabular}{|c|c|c|}
\hline Variable & $\begin{array}{l}{ }^{\#} \text { No of } \\
\text { response }\end{array}$ & $\%$ \\
\hline \multicolumn{3}{|l|}{$\begin{array}{l}\text { Attitude towards eliminating mosquitoes } \\
\text { from our homestead }\end{array}$} \\
\hline No, because mosquitoes are created by God & 17 & 8.4 \\
\hline $\begin{array}{l}\text { Mosquitoes come with rain no one can } \\
\text { control them }\end{array}$ & 35 & 17.3 \\
\hline No, mosquitoes are only seen after sun set & 14 & 6.9 \\
\hline Yes, by eliminating stagnant water & 81 & 40.1 \\
\hline Yes, by closing widows and doors & 22 & 10.9 \\
\hline Yes, by using indoor insecticide residual spray & 65 & 32.2 \\
\hline Yes, by spraying insecticide in stagnant water & 91 & 45.0 \\
\hline Yes, by using ITN & 77 & 38.1 \\
\hline \multicolumn{3}{|l|}{ Participation in mosquito control } \\
\hline $\begin{array}{l}\text { Destroying or avoid creating stagnant water } \\
\text { bodies }\end{array}$ & 118 & 58.4 \\
\hline It is the responsibility of the government & 9 & 4.5 \\
\hline $\begin{array}{l}\text { Wait for the directives from the district malaria } \\
\text { control focal person }\end{array}$ & 8 & 4.0 \\
\hline Community based programs of cleaning bushes & 72 & 35.6 \\
\hline $\begin{array}{l}\text { Community based programs of applying safe } \\
\text { insecticides in stagnant waters }\end{array}$ & 69 & 34.2 \\
\hline \multicolumn{3}{|l|}{ Reliance of plants as source of insecticides } \\
\hline We use them often & 35 & 17.3 \\
\hline It is an old practice & 46 & 22.8 \\
\hline We have many plants around us & 54 & 26.7 \\
\hline Not harmful like insecticides bought in the shop & 40 & 19.8 \\
\hline Plants are affordable, unlike insecticides & 59 & 29.2 \\
\hline
\end{tabular}

"Multiple responses were included. (the use of which is reported for the first time), all plants mentioned have been either reported to be used traditionally elsewhere to control some insects or investigated scientifically and evidence on the presence of anti-insect phytochemicals generated (Table 8). Interestingly, control methods deployed in the ethnobotanical practices, as well as scientific investigations undertaken, both targeted repellency and/or larvidical properties, similar to the use of the plants by the communities in Bagamoyo district (Tables 4 and 8 ).

\section{Discussion}

The Government of Tanzania has invested in a number of interventions aimed at alleviating mosquito-borne diseases such as malaria and lymphatic filariasis. These include improving diagnosis and treatment of the diseases, provision of subsidized anti-malarial (ALU) drugs, and use of insecticide-treated nets (ITN). Elsewhere, history and scientific evidence show that the battle against mosquito-borne diseases has succeeded significantly through massive spraying with DDT $[38,39]$, although ecological unfriendliness of the insecticide has made its continued use very controversial. However, this may have opened up the use of plant natural products with subtle anti-insect effects as a better alternative in reducing the burden of mosquito-borne diseases. Specific tropical plants are readily accessible by rural communities, and are eco-friendly and costeffective.

Although only $40.3 \%$ of the respondents in the Bagamoyo District reported using plants in the control of insects and especially mosquitoes. Many of the mentioned plants are exotic, although they were introduced on the African coastal area long time ago, and are from plant families with anti-insect activities [40-42]. Of special significance is that the majority of respondents were open to the possibility of using a combination of different methods in an integrated vector management and were aware of different diseases caused by mosquito species such as malaria, elephantiasis/hydrocele and yellow fever. This could be attributed to regular communitybased sensitizations from other malaria interventions such as the Bagamoyo Bednet $[3,43,44]$ and on-going Malaria Vaccine Trial [45]. The present study identified the need for regular outreach education on proper deployment of anti-insect plants within rural communities where there is continued use of this natural resource to add value to the current mosquito and malaria control strategies. Further R\&D on the plant products deployed, their efficacy and modes of action would lay down the groundwork for selecting those that are particularly effective in different uses and in optimizing their deployment. 
Table 8 An overview of Insecticidal plant efficacy from literature review of selected species mentioned in the Bagamoyo survey

\begin{tabular}{|c|c|c|c|c|c|}
\hline & Swahili name & Species/genus name & $\begin{array}{l}\text { Name of other related } \\
\text { species growing in Tanzania }\end{array}$ & $\begin{array}{l}\text { Related Ethno botanical uses } \\
\text { in insect management }\end{array}$ & Scientific studies \\
\hline \multirow[t]{3}{*}{1} & \multirow[t]{3}{*}{ Mwarobaini } & \multirow[t]{3}{*}{$\begin{array}{l}\text { Azadirachta indica } \\
\text { (Maliaceae) }\end{array}$} & & \multirow{3}{*}{$\begin{array}{l}\text { In Tanzania, leaves mixture with cow urine controls maize } \\
\text { pests in the field; Also, infusion of leaves and tobacco } \\
\text { powder are sprayed to control crop pests in the field [8] }\end{array}$} & $\begin{array}{l}\text { Dried leaf powder is used to repel Culex } \\
\text { quinquefasciatus [9]. }\end{array}$ \\
\hline & & & & & Larvicidal activity against Aedes aegyptis [10]. \\
\hline & & & & & \\
\hline \multirow[t]{2}{*}{2} & Mtopetope; & \multirow[t]{3}{*}{ Annona squamosa } & Annona cherimoya & \multirow{3}{*}{$\begin{array}{l}\text { Indians use leaf, bark, root, stem and fruits for control } \\
\text { of head lice and insects [11]. }\end{array}$} & \multirow{3}{*}{$\begin{array}{l}\text { Leaf extract of } A \text {. senegalensis and } A \text {. squamosa is used } \\
\text { against mosquito larvae }[12,13] \text {. }\end{array}$} \\
\hline & Mtopetope & & Annona reticulata $\mathrm{L}$. & & \\
\hline & mwitu; & & Annona stenophylla & & \\
\hline & Mtomoko & \multirow{5}{*}{$\begin{array}{l}\text { Annona senegalesis } \\
\text { (Annonaceae) }\end{array}$} & Engl. [14,15]. & \multirow{5}{*}{$\begin{array}{l}\text { Annona senegalensis Pers is used traditionally } \\
\text { in Nigeria to treat victims of snakebite [16]. }\end{array}$} & \multirow[t]{2}{*}{ Also leaf extract is used against Aedes adopticus [17]. } \\
\hline & Mchekwa; & & Annona Montana [18]. & & \\
\hline & \multirow[t]{3}{*}{ Mtopetope pori } & & & & Annona senegalensis \\
\hline & & & & & $\begin{array}{l}\text { leaves was effective against different stages of Caryedon } \\
\text { serratus }\end{array}$ \\
\hline & & & & & development [19]. \\
\hline \multirow[t]{7}{*}{3} & \multirow[t]{7}{*}{ Mchugwa; Limau } & \multirow[t]{7}{*}{ Citrus spp (Rutaceae) } & C. aurantifolia & \multirow{7}{*}{$\begin{array}{l}\text { Dried leaf of } C \text {. limonium is used against wheat } \\
\text { weevil and flour beetle by Indians }[11,20] \text {. }\end{array}$} & \multirow{5}{*}{$\begin{array}{l}\text { Essential oils of C. aurantifolia, C. paradis, C. sinensis and } \\
\text { C. limonium is used for control of Cowpea weevils } \\
\text { (Callosobruchus maculatus) [21]. }\end{array}$} \\
\hline & & & C. paradis & & \\
\hline & & & C. sinensis & & \\
\hline & & & C. limonium & & \\
\hline & & & C. aurantium & & \\
\hline & & & C. reticulate Blanco $[14,15]$. & & $\begin{array}{l}\text { C. aurantium. Essential oils are used to control tomato } \\
\text { moth (Tuta absoluta) and Africa cotton leaf worm. } \\
\text { (Spodoptera littoralis) [22]. }\end{array}$ \\
\hline & & & & & $\begin{array}{l}\text { Show bioefficacy against Ae. albopictus of three Citrus } \\
\text { essential oils, derived from peels of Citrus sinensis, Citrus } \\
\text { limon, and Citrus paradise and of their component [23]; } \\
\text { Also against An. gambiae [24]. }\end{array}$ \\
\hline \multirow[t]{6}{*}{4} & Mvumbashi & \multirow{6}{*}{$\begin{array}{l}\text { Ocimum Spp } \\
\text { (Laminaceae) }\end{array}$} & O. americanum & \multirow{3}{*}{$\begin{array}{l}\text { Leaves of } O \text {. suave are arranged in a bag of millet } \\
\text { or maize to control pests [8]. }\end{array}$} & \multirow{3}{*}{$\begin{array}{l}\text { Essential oils of } O \text {. suave and } O \text {. kilimandscharium are } C X \text {. } \\
\text { Quinquefasciatus and Anopheles arabiensis repellant [25]. }\end{array}$} \\
\hline & \multirow[t]{5}{*}{ Uvumbati } & & O. suave & & \\
\hline & & & O. Iamiifolium & & \\
\hline & & & O. polystachyon & \multirow{3}{*}{$\begin{array}{l}\text { Leaves of } O . \text { gratissimum are used in Nigeria in } \\
\text { post harvest protection of maize [26]. }\end{array}$} & \\
\hline & & & O. grantissimum & & \multirow{2}{*}{$\begin{array}{l}\text { Essential oils of } O \text {. canum and O. basilicum are used for } \\
\text { control of Cowpea weevils (Callosobruchus maculatus) [27]. }\end{array}$} \\
\hline & & & O. kilimandscharium & & \\
\hline
\end{tabular}


Table 8 An overview of Insecticidal plant efficacy from literature review of selected species mentioned in the Bagamoyo survey (Continued)

\begin{tabular}{|c|c|c|c|c|c|}
\hline & & & $\begin{array}{l}\text { Hyptis suaveolens (Formally, } \\
\text { O. basilicanum) }\end{array}$ & & \multirow{3}{*}{$\begin{array}{l}\text { High protection time of essential oil of O. basilicum with ethyl } \\
\text { alcohol, tested against three mosquito species, Aedes aegypti, } \\
\text { Anopheles minimus and Culex quinquefasciatus [28]. }\end{array}$} \\
\hline & & & {$[14,15]$} & & \\
\hline & & & O. albosteblatum & & \\
\hline & & & O. angustifolium & & \multirow{2}{*}{$\begin{array}{l}\text { O. gratissimum essential oil formulation repelled anopheline } \\
\text { and culicine mosquitoes [29]. }\end{array}$} \\
\hline & & & O. obovatum [14]. & & \\
\hline & & & & & $\begin{array}{l}\text { O. basilicum essential oil showed the strongest larvicidal } \\
\text { activity while } O \text {. gratissimum exhibited the longest duration } \\
\text { of action for mosquito repellent activity [30]. }\end{array}$ \\
\hline \multirow[t]{2}{*}{5} & Mkorosho & $\begin{array}{l}\text { Anacardium occidentale } \\
\text { (Anacardiaceae) }\end{array}$ & & $\begin{array}{l}\text { The gum from stem of A. occidentale is used as an } \\
\text { adhesive (for woodwork panels, plywood, bookbinding), } \\
\text { partly because it has insecticidal properties [31]. }\end{array}$ & $\begin{array}{l}\text { Powders and extracts of A. occidentale seeds were effective } \\
\text { in controlling cowpea bruchid, C. maculatus in stored } \\
\text { cowpea seeds [32]. }\end{array}$ \\
\hline & & & & & $\begin{array}{l}\text { Larvicidal activities of aqueous extracts of Leaf, Bark and } \\
\text { Nutshell of A. occidentale showed insecticidal properties } \\
\text { on the An. gambiae [33]. }\end{array}$ \\
\hline 6 & Mstafeli & An.muricata & & $\begin{array}{l}\text { Leaves of An. muricata are used by phu thai tribe in Lao } \\
\text { People's Democratic Republic to repel bedbugs and lice [20]. }\end{array}$ & $\begin{array}{l}\text { Annona muricata shows promising larvicidal activity } \\
\text { against Ae. Eagypti }[13,34] \text {. }\end{array}$ \\
\hline \multirow[t]{2}{*}{7} & Mwembe & Mangifera indica & & Leaves of M. indica is used in uMkhanyakude district, & \\
\hline & & (Myrtaceae) & & $\begin{array}{l}\text { KwaZulu-Natal province, South Africa as mosquito } \\
\text { insect repellent [35]. }\end{array}$ & \\
\hline \multirow[t]{2}{*}{8} & Maganda ya nazi & Cocos nucifera & & & Coconuts oil is used as mosquito and tick repellant $[36,37]$. \\
\hline & & (Arecaceae) & & & \\
\hline \multirow[t]{4}{*}{9} & Mpera & Psidium Spp & P. guajava & & \\
\hline & & (Myrtaceae) & P. cattleianum & & \\
\hline & & & P. friedrichsthalianum & & \\
\hline & & & P. guineese $([14,15])$. & & \\
\hline
\end{tabular}




\section{Conclusion}

The present survey indicates that a good proportion of members of different communities in Bagamoyo District continue to use plants to control different disease vectors and other pests and that the majority are open to the possibility of integrating them with other interventions. Continued use of these medicinal plants needs to be encouraged and promoted as they have potential for complementing other interventions in vector and disease control. Tanzania has no clear policy or guidelines on development, registration and use of botanical insecticides. Elsewhere, some botanical insecticides have been developed for multipurpose uses in pest control, including mosquito control. This calls for the government to strengthen advocacy of botanical pesticides development, registration and regulation for public health benefits.

\section{Competing interests}

The authors declare that they have no competing interests.

\section{Authors' contributions}

$\mathrm{IE}, \mathrm{MSM}$ and HA contributed to the study conception, design, fieldwork, data analysis, interpretation and drafting, revision and final approval of the manuscript. KNW, MPP and KE contributed to fieldwork, data analysis, data interpretation, revision and final approval of the manuscript. All authors read and approved the final manuscript.

\section{Acknowledgement}

We are thankful to the Office of the District Medical Officer and District Community Development Officer, village leaders and study participants for their willingness to collaborate with researchers. We are thankful to DelPHE-British Council for the funds to carry out this study.

\section{Author details}

${ }^{1}$ Institute of Traditional Medicine, Muhimbili University of Health and Allied Sciences, P.O. Box 65001, Dar es Salaam, Tanzania. ²Department of Chemistry, School of Pure \& Applied Sciences, Kenyatta University, P.O. Box 43844-00100, Nairobi, Kenya. ${ }^{3}$ National Institute for Medical Research (NIMR), Amani Research Centre, P.O. Box 81, Muheza, Tanzania. ${ }^{4}$ RTI International, Malaria Initiative, P.O. Box 1181-000621, Nairobi, Kenya.

Received: 31 October 2013 Accepted: 1 July 2014

Published: 11 July 2014

\section{References}

1. WHO: Global Strategic Framework for Integrated Vector Management. Geneva: WHO; 2004.

2. Ministry of Health: Health Sector Strategic Plan III (2009-2015); Partnerships for Delivering MDGs. Tanzania: Ministry of Health; 2009.

3. Premji Z, Ndayanga P, Shiff C, Minjas J, Lubega P, MacLeod J: Community based studies on childhood mortality in a malaria holoendemic area on the Tanzanian coast. Acta Trop 1997, 63:101-109.

4. Davis JR, Hall T, Chee EM, Majala A, Minjas JN, Shiff CJ: Comparison of sampling anopheline mosquitoes by light-trap and human-bait collections indoors at Bagamoyo, Tanzania. Med Vet Entomol 1995, 9:249-255.

5. Kawada H, Emmanuel A, Temu J, Minjas N, Matsumoto O, Iwasaki T, Takagi M: Field evaluation of spatial repellency of metofluthrin impregnated plastic strips against anopheles gambiae complex in Bagamoyo, coastal Tanzania. J Am Mosq Control Assoc 2008, 24:404-409.

6. Shiff CJ, Minjas JN, Hall T, Hunt RH, Lyimo S, Davis R: Malaria infection potential of anopheline mosquitoes sampled by light trapping indoors in coastal Tanzania villages. Med Vet Entomol 1995, 9:256-262.

7. Temu EA, Minjas JN, Coetzee M, Hunt RH, Shift CJ: The role of four anopheline species (Diptera: Culicidae) in malaria transmission in coastal Tanzania. Trans Royal Soc Trop Med Hyg 1998, 92:152-158.
8. Mihale MJ, Dang AL, Selemani HO, Mugisha-Kamatanesi M, Kidukuli AW, Ogendo O: Use of indigenous knowledge in the management of field and storage pests around Lake Victoria basin in Tanzania. Afr J Environ SciTech 2009, 3:251-259.

9. Su T, Mulla AS: Effects of neem products containing azadirachtin on blood feeding, fecundity, and survivorship of Culex tarsalis and Culex quinquefasciatus (Diptera: Culicidae). J Vector Ecol 1999, 24:202-215.

10. Ndione RD, Faye $O$, Ndiaye M, Afoutou JM: Toxic effects of Neem products (Azadirachta indica A Juss) on Aedes aegypti Linnaeus 1763 larvae. Afr J Biotechnol 2007, 6:2846-2854.

11. Sharma PP, Sawant RJ: Indigenous traditional practices for eco-friendly management of the insect/pests in Maharashtra, India. Recent Res Sci Tech 2012, 4:21-24.

12. Daniel B, Innocent E, Mbwambo ZH, Musharraf SG: Comparison of Mosquito Larvicidal activitity of Annona squamosa leaves growing in different eco-zone in Tanzania. Int JPharma Bio Sci 2011, 2:557-565.

13. Magadula JJ, Innocent E, Otieno NJ: Mosquito larvicidal and cytotoxicactivity of 3 Annona species and Isolation of active principles. J Med Plant Res 2009, 3:674-680.

14. Ruffo CK, Chilongola SB, Mabula CK: Catalogue of Lushoto Herbarium Tanzania. National Tree Seed Program. Morogoro, Tanzania; 1996.

15. Gideon H, Nyinondi P, Oyema G: Checklist of Tanzania species, Version 1. Tanzania: TanBIF COSTECH; 2012.

16. Adzu B, Abubakar MS, Izebe KS, Akumka DD, Gamaniel KS: Effect of Annona senegalensis rootbark extracts on Naja nigricotlis nigricotlis venom in rats. J Ethnopharmacol 2005, 96:507-513.

17. Das NG, Goswami D, Rabha B: Preliminary evaluation of mosquito larvicidal efficacy of plant extract. J Vector Borne Dis 2007, 44:147-148.

18. Kisanga AC: Effect of Annona Formulations on Mosquitoes and non-Target Invertebrates in the Laboratory and Semi-Field Condition, MSc. Thesis. Tanzania: University of Dar es Salaam; 2013.

19. Gueye S, Diop MT, SecK D, Sembene M: Biochemical fractions activity of Annona senegalensis Pers. Extract leaves to protect groundnut against the seed-beetle Caryedon serratusol. (Coleoptera, Chrysomelidea, Bruchinae). Int J Plant. Animal Environ Sci 2011, 1:122-130.

20. De Boer H, Vongsombath C, Pålsson K, Bjork L, Jaenson TGT: Botanical repellents and pesticides traditionally used against hematophagous invertebrates in lao people's democratic republic: a comparative study of plants used in 66 village. J Med Entomol 2010, 47:400-414.

21. Rotimi J, Ekperusi OA: Effectiveness of Citrus oils as cowpea seed protectant against damage by the cowpea Bruchid Collosobruchus maculatus (F) (Coleopteran: Bruchidae). Adv Applied Sci Res 2012, 3:3540-3544.

22. Laarif A, Zarrad K, Tayeb W, Ayed A, Souguirs S, Chaieb I: Chemical composition and Insecticidal activity of essential oils from Citrus aurantium (Rutaceae) Fruits Peels against two greenhouse insects; Spodoptera littoralis (Noctuidae) and Tuta absoluta (Gelechiidae). Adv Agric Sci and Eng Res 2013, 3:825-830.

23. Giatropoulos A, Papachristos DP, Kimbaris A, Koliopoulos G, Polissiou MG, Emmanuel N, Michaelakis A: Evaluation of bioefficacy of three Citrus essential oils against the dengue vector Aedes albopictus (Diptera: Culicidae) in correlation to their components enantiomeric distribution. Parasitol Res 2012, 111:2253-2263.

24. Oshaghi MA, Ghalandari R, Vatandoost H, Shayeghi M, Kamali-nejad M, Tourabi-Khaledi H, Abolhassani M, Hashemzade M: Repellent effect of extracts and essential oils of Citrus limon (Rutaceae) and Melissa officinalis (Labiatae) against main malaria vector, Anopheles stephensi (Diptera: Culicidae). Iranian J Public Health 2003, 32:47-52.

25. Kweka JE, Franklin WM, Asanterabi L, Mahande AM, Mahande MJ, Massenga CP, Temu F, Lyatuu EE, Mboya M, Temu EA: Longitudinal evaluation of Ocimum and other plants effects on the feeding behavioural responses of mosquitoes (Diptera: Culicidae) in the field in Tanzania. Parasite Vectors 2008, 1:42

26. Asawalam EF, Emosairue SO, Hassanali A: Essential oil of Ocimum grattissimum (Labiatae) as Sitophilus zeamais (Coleoptera: Curculionidae) protectant. Afr J Biotechnol 2008, 7:3771-3776.

27. Keita SM, Vincent C, Schmit JP, Ramaswamy S, Belanger A: Effects of various essential oils on Callosobruchus maculatus (F) (Coleoptera: Bruchidae). J Stored Products Res 2000, 36:355-364.

28. Phasomkusolsil S, Soonwera M: Insect repellent activity of medicinal plant oils against Aedes aegypti (Linn.), Anopheles minimus (Theobald) and 
Culex quinquefasciatus Say based on protection time and biting rate. Southeast Asian J Trop Med Public Health 2010, 41:831-840.

29. Malebo HM, Imeda C, Kitufe NA, Katani SJ, Sunguruma R, Magogo F, Tungu PK, Nyigo VA, Wiketye V, Mwaiko GL, Ogondiek JW, Mbogo GP, Mhame PP, Matata DZ, Malima R, Magesa SM, Massaga JJ, Malecela MN, Kitua AY: Repellence effectiveness of essential oils from some Tanzanian Ocimum and Hyptis plant species against afro-tropical vectors of malaria and lymphatic filariasis. J Med Plants Res 2013, 7:653-660.

30. Chokechaijaroenporn O, Bunyapraphatsara N, Kongchuensin S: Mosquito repellent activities of Ocimum volatile oil. Phytomedicine 1994, 1:135-139.

31. Orwa C, Mutua A, Kindt R, Jamnadass R, Simons A: Agroforestree Database:A Tree Reference and Selection Guide Version 4.0. (http://www.worldagroforestry. org/treedb/AFTPDFS/Anacardium_occidentale.pdf): 2009.

32. Ileke KD, Olotuah OF: Bioactivity of Anacardium occidentale (L) and Allium sativum (L) powders and Oils Extracts against Cowpea Bruchid, Callosobruchus maculatus (Fab.) [Coleoptera: Chrysomelidae]. Int I Biol 2012, 4:96-103.

33. Nnamani CV, Osayi EE, Atama Cl, Nwachukwu C: Larvicidal effects of leaf, bark and nutshell of Anacardium occidentale on the larvae of Anopheles gambiae In Ebonyi State, Nigeria. Animal Res Int 2011, 8:1353-1358.

34. Promsiri S, Naksathit A, Kruatrachue M, Thavara A: Evaluations of larvicidal activity of medicinal plant extracts to Aedes aegypti (Diptera: Culicidae) and other effects on a non target fish. Ins Sci 2006, 13:179-188.

35. Mavundza EJ, Maharaj R, Finnie JF, Kabera G, Van Staden J: An ethnobotanical survey of mosquito repellent plants in uMkhanyakude district, KwaZulu-Natal province, South Africa. J Ethnopharmacol 2011, 137:1516-1520.

36. Mandal MD, Mandal S: Coconut (Cocos nucifera L: Arecaceae): in health promotion and disease prevention. Asian Pacific J Trop Med 2011, 1:241-247.

37. Konan YL, Sylla MS, Doannio JM, Traoré S: Comparison of the effect of two excipients (karite nut butter and vaseline) on the efficacy of Cocos nucifera, Elaeis guineensis and Carapa procera oil-based repellents formulations against mosquitoes biting in Ivory Coast. Parasite 2003, 10:181-184.

38. Gourevitch A: Better Living Through Chemistry; Ddt Could Save Millions of Africans From Dying of Malaria- If Only Environmentalists Would Let It. WA: Washington Monthly; 2003.

39. East African Community HEALTH: Malaria facts: Malaria Prevention and Control. http://www.eac.int/health/index.php?option=com_content\&view=article\&id= 95\%3Aclassification-system\&catid=15\%3Adiseases\&ltemid=32" - Retrieved on 05th December, 2012

40. Watt MJ, Breyer-Brandwijk GM: Medicinal and Poisonous Plants of Southern and Eastern Africa. Edinburg and London: E and S Livingstone Ltd; 1962.

41. Gilbert MG: Flora of Ethiopia, Rutaceae. Sweden: University of Ethiopia and Uppsala University Press; 1989.

42. Hutching A, Haxtonscott A, Lewis G, Cunninghham A: Zulu Medicinal Plants, an Inventory. Scottsville, South Africa: University of Natal Press; 1996.

43. Bagamoyo bednet project: An Annual Report. Tanzania: USAID; 1991.

44. Shiff CJ, Winch P, Minjas J, Premji Z: The Implementation and Sustainability of Insecticide-Treated Mosquito net (ITN) Program for Malaria Control in Rural Africa. Lesson Learned from the Bagamoyo Bednet Project. A Summary Report. Tanzania: USAID, SARA and HHRAA; 1996.

45. Medicine for Malaria Venture (MMV): New Malaria Clinical Trial Site Inaugurated at Bagamoyo, Tanzania. http://www.mmv.org/newsroom/news/ new-malaria-clinical-trial-site-inaugurated-bagamoyo-tanzania. Deposited on 10 May 2007; accessed on 09/02/2012

doi:10.1186/1746-4269-10-56

Cite this article as: Innocent et al:: Anti-mosquito plants as an alternative or incremental method for malaria vector control among rural communities of Bagamoyo District, Tanzania. Journal of Ethnobiology and Ethnomedicine 2014 10:56.

\section{Submit your next manuscript to BioMed Central and take full advantage of:}

- Convenient online submission

- Thorough peer review

- No space constraints or color figure charges

- Immediate publication on acceptance

- Inclusion in PubMed, CAS, Scopus and Google Scholar

- Research which is freely available for redistribution 